\title{
Effect of Nitrogen, Phosphorus and Medium pH to Enhance Alkaloid Production from Catharanthus roseus Cell Suspension Culture
}

\author{
Malay Ranjan Mishra ${ }^{(\mathbb{D})}$, Rajesh Kumar Srivastava(i)1, Nasim Akhtar (iD)*,1
}

\author{
${ }^{1}$ Department of Biotechnology, GITAM Institute of Technology, Gandhi Institute of Technology \\ and Management, GITAM Deemed to be University, Rushikonda, Visakhapatnam (A.P.), India
}

\begin{abstract}
Several elevated levels of nitrogen and phosphate at varying $\mathrm{pH}$ of the medium which impart a major influence on callus and biomass development and subsequent production of alkaloids was investigated using suspension culture system of Catharanthus roseus in the present study. The B5 medium was buffered at $\mathrm{pH} 4.51,5.82$ and 7.32 by addition of different levels of (A) diammonium hydrogen phosphate $\left(\mathrm{NH}_{4}\right)_{2} \mathrm{HPO}_{4}$ and (B) ammonium dihydrogen orthophosphate $\left(\mathrm{NH}_{4} \mathrm{H}_{2} \mathrm{PO}_{4}\right)$ representing the enhanced and varied supply of total nitrogen $\left(\mathrm{NH}_{4}{ }^{+}+\mathrm{NO}_{3}{ }^{-}\right)$and phosphate compared to MS medium (as control) for cell biomass production and alkaloid yield. The $\mathrm{pH}$ of the medium have shown significant effects with maximum biomass fresh wt., dry wt. and total alkaloid yield at 5.82 medium $\mathrm{pH}$ with elevated phosphate levels and total nitrogen concentration of $3710.10 \mathrm{mg} / \mathrm{L}$ compared to control MS medium with $2850 \mathrm{mg} / \mathrm{L}$ total nitrogen. At 3667.33 and $3752.48 \mathrm{mg} / \mathrm{L}$ of total nitrogen with enhanced phosphate supply showed reduced biomass fresh wt., dry wt. and total alkaloid yield at lower (4.51) and higher (7.32) medium $\mathrm{pH}$ respectively. Inclusion of 200 $\mathrm{mg} / \mathrm{L}$ of tryptophan or phenylalanine as reduced nitrogen source in B5 medium buffered at $5.82 \pm 0.2 \mathrm{pH}$ showed enhanced biomass and alkaloid production. Hence, addition of nitrogen, phosphate, tryptophan, phenylalanine as nutrient in suspension culture stimulate their uptake to enhance cell biomass and total alkaloids production but as a function of $\mathrm{pH}$ of the medium.
\end{abstract}

\section{ARTICLE HISTORY}

Received: February 05, 2019

Revised: March 11, 2019

Accepted: April 30, 2019

\section{KEYWORDS}

Alkaloid,

Catharanthus roseus,

medium $\mathrm{pH}$,

Nitrogen,

Phenylalanine,

Phosphorus,

Tryptophan

\section{INTRODUCTION}

The plant cell, tissue and organs cultured in vitro need to be supplied with complete nutrients in the medium [1]. Nitrogen and phosphate comprises the most important essential elements required for all plants growth and developmental process by feeding to the major metabolic pathways [2-6]. The nitrogen is available as nitrate and ammonia in the soil which are absorbed by plants through roots [7-9]. The nitrate gets transported through xylem reaches

\footnotetext{
${ }^{*}$ CONTACT: Nasim AKHTAR $\square$ nasimakhtar111@gmail.com $\equiv$ Department of Biotechnology, GITAM Institute of Technology, Gandhi Institute of Technology and Management, GITAM Deemed to be University, Rushikonda, Visakhapatnam (A.P.), India
} 
to the parenchymatous cells of root and shoot wherein it is stored in vacuoles and does not cause any toxicity to the plants but need to be converted to the active form ammonia for metabolisms leading to growth, development and stress tolerance [10]. The uptake of nitrate is dependent on various factors like plant species, root $\mathrm{pH}$, temperature etc. [11]. The energy required for ammonium assimilation is low in comparison to nitrate. To avoid the toxicity in roots of the plants ammonia is immediately converted to organic biomolecules [12]. In suspension culture of $C$. roseus the effect of UV-B and nitrate was compared individually as well as in combinations for cell biomass growth and alkaloid accumulation [13]. The increased supply of nitrogen inhibited the repair mechanism of the cell for UV-B radiation damages as under decreased N supply, plant becomes sensitive to UV radiation [14].

Nitrate supplied as nutrients was found as an important factor in alkaloid production by C. roseus plants under salinity stress [15]. On the other hand, changes in many growth parameters such as reduction of biomass, leaf epidermis damages, change in leaf colour and leaf fall due to reduced resistance was implicated with excess $\mathrm{N}$ deposition in plants [16]. It has also been reported that secondary metabolite production is affected differently by nitrate and ammonia, where nitrate promote secondary metabolite synthesis but ammonium ions inhibit it [17-18].

The importance of phosphate in secondary metabolite production was demonstrated as depletion of its level showing decreased biomass and 20-hydroxyecdysone (20-HE) production in hairy root culture of Ajuga [19]. On the other hand, C. roseus batch culture added with different phosphate concentrations showed increased cell growth and alkaloids with higher intracellular phosphate level [20].

Catharanthus roseus a perennial medicinal herb of family Apocynaceae is the store house of more than 130 secondary metabolites. The most important are the alkaloids (vincristine and vinblastine) with anti-cancer activity, anti-hypertension (ajmalicine and serpentine) [21]. Majority of alkaloids possess nitrogen containing heterocyclic reaction centers for these activities. But the problem with these alkaloids is very low concentrations and gets stored in leaf vacuoles. As the genes involved in alkaloid synthesis are expressed in tissue specific manner might be the cause of its low yield [22-24].

Biosynthesis of alkaloids by $C$. roseus cell gets initiated by joining of amino acid and a monoterpenoid i.e. tryptophan and geraniol respectively. The whole process is expressed by the involvement of two regulatory genes controlling about 30 biosynthetic steps catalyzed by 30 enzymes to produce 35 intermediates compartmentalized among 7 intra- and inter- cellular components [25]. This emphasizes the importance of tryptophan in TIA biosynthesis. Addition of tryptophan, secologanin, phenylalanine etc as precursor have been applied in cell suspension and hairy root culture of $C$. roseus to enhance the alkaloid production [26-27]. The effect of tryptophan on metabolic flux of indole alkaloids in Catharanthus revealed tryptophan feeding at 17 days of culture mimicked auxin effect on the cultures and increased the flux density of the indole alkaloids [27].

Precursor feeding as elicitation is an important strategy for increasing secondary metabolite productions in plants [28]. Plants like Crocus sativus also showed enhanced ajmalicine and strictosidine production upon treatment with exogenous tryptamine and loganic acid [29]. The induced production of enzyme phenylalanine ammonia lyase (PAL) and tryptophan decarboxylase (TDC) in cell suspension culture of C. roseus are involved in the production of phenylalanine and tryptophan respectively [30]. The 2 amino acids are the branched point product of common intermediate chorismate of the pathway and serve as the precursors for the synthesis of phenolics and indole alkaloids. The shikimate and terpenoid pathway catalyzed the production of tryptamine and secologanin which are combined to produce strictosidine, the precursor for monomeric alkaloid ajamalicine, catharanthine and 
vindoline. The coupling reaction between catharanthine and vindoline catalyzed by anhydrovinblastine synthase (AVLBS) to produce vinblastine from a-3',4'- anhydrovinblastine whose mechanism of conversion is still unclear [30]. Hence, the regulation of alkaloid production by $C$. roseus in response to nitrate and other cultural and environmental factors is not fully understood and need to be explored in detail.

There is pressing need for an alternative strategy for natural sources to produce enhanced level of alkaloids and other desirable substances. Therefore attempts are made in the present investigation to investigate the role of nitrogen along with phosphate for biomass growth leading to higher alkaloid production in suspension medium with varying $\mathrm{pH}$. The experiments are designed to maintain different $\mathrm{pH}$ of the medium by buffering action with higher levels of nitrogen and phosphate as well as supplemented with reduced nitrogen (tryptophan and phenylalanine) sources to enhance total alkaloid synthe sis.

\section{MATERIALS and METHODS}

\subsection{Selection of Plants and Preparation Explants}

Catharanthus roseus plants grown as seedlings in the GITAM campus nursery were used for explant supply. Successful establishment of callus was induced only from leaf segments as other explants were not successful. Induction of callus was achieved by culturing $1 \mathrm{~cm}^{2}$ as described earlier [31-33].

\subsection{Culture Media and Treatments}

The normal strength of Murashige and Skoog's (MS) [1] and Gamborgh's (B5) culture medium [34] containing 3\% (w/v) sucrose and modified with $0.50 \mathrm{mg} / \mathrm{L}$ of $2,4-\mathrm{D}, 1.0 \mathrm{mg} / \mathrm{L}$ of Kinetin and $2.0 \mathrm{mg} / \mathrm{L} \mathrm{NAA}$ was used as the standard treatments for the induction of callus and cell proliferations in suspension cultures. Callus induction from leaf explants and multiplication was achieved by continuous incubation for four weeks in the presence of this standard treatment on agar medium. The cell suspension culture was established in normal strength B5 culture salts with above standard treatment for control and modified variously for different treatments. About $100 \mathrm{ml}$ of suspension medium was modified for each treatment and dispensed $25 \mathrm{ml}$ in 4 conical flasks of $150 \mathrm{ml}$ capacity. Each $25 \mathrm{ml}$ suspension medium was inoculated either with $100-150 \mathrm{mg}$ friable callus (4-weeks old) from agar medium or with $5 \mathrm{ml}$ of 2-weeks old suspension cultures.

The $\mathrm{pH}$ of the MS medium was adjusted to $5.8 \pm 0.2$. To study the effect of $\mathrm{pH}$ the B5 medium was buffered at $4.51 \pm 0.2,5.82 \pm 0.2$ and $7.32 \pm 0.2$ by the addition of specific volumes of molar concentrations of i) ammonium di-hydrogen orthophosphate $\left(\mathrm{NH}_{4} \mathrm{H}_{2} \mathrm{PO}_{4}\right)$ and ii) diammonium hydrogen phosphate $\left(\left(\mathrm{NH}_{4}\right)_{2} \mathrm{HPO}_{4}\right)$ along with standard sucrose and PGR combination. The B5 control and medium buffered at $\mathrm{pH} 5.82 \pm 0.2$ was also supplemented with $0-200 \mathrm{mg} / \mathrm{L}$ of reduced nitrogen sources either as tryptophan or as phenylalanine as precursor feeding in alkaloid biosynthetic pathway.

All these media were sterilized by autoclaving $\left(15 \mathrm{lbs}, 121^{\circ} \mathrm{C}, 15 \mathrm{~min}\right)$. The suspension cultures were maintained under continuous shaking at $150 \mathrm{rpm}$ over an orbital shaker incubator at $25 \pm 2{ }^{\circ} \mathrm{C}$. The callus cultures were maintained in an environmentally controlled air conditioned room. Each culture shelves were fitted with fluorescent lamps providing 2,0003,000 Lux photon flux density under 16/8 hrs photoperiodic cycle. 


\subsection{Growth Measurement}

\subsubsection{Callus growth}

Induction and proliferation of callus from leaf explants was achieved as described by [3133]. The callus grown on agar medium was harvested after 4-weeks of sub-culture. The cell biomass from suspension culture was harvested every 2- weeks of culture/sub-culture. The procedure for measurement of fresh and dry weight of callus and cell biomass was described earlier [31-33] and represented as:

Callus Fresh $\mathrm{Wt}=\{$ Weight of filter paper and the callus - Initial weight of dried filter paper $\}$ Callus Dry Wt $=\{$ Weight of dried callus along with filter paper - Initial weight of dried filter paper\}

Biomass Fresh $\mathrm{Wt}=\{$ Weight of moisture free filter paper and the cell biomass - Initial weight of moisture free filter paper\}

Biomass Dry $\mathrm{Wt}=\{$ Weight of the dried Biomass with Filter Paper - Weight of the dried Filter Paper\}

\subsection{Extraction and Quantifications of Total Alkaloids}

Alkaloids were extracted using $20 \mathrm{mg}$ dried callus or cell biomass following the procedure detailed in by [31-33]. The total alkaloid was estimated following the modification of protocol $[35 ; 36]$ along with Bismuth nitrate pentahydrate $\left(\mathrm{Bi}\left(\mathrm{NO}_{3}\right)_{3} .5 \mathrm{H}_{2} \mathrm{O}\right)$ calibration curve. The alkaloid content was calculated as described earlier [31-33] and presented as:

Alkaloid content (mg/g dwt): \{(Concentrations $(\mu \mathrm{g}) / 10 \mathrm{mg}$ Dry weight $\}$ x 1000

Alkaloid Production $(\mathrm{mg} / \mathrm{L})=$ Dry wt $(\mathrm{g} / \mathrm{L}) \times$ Alkaloid content $(\mathrm{mg} / \mathrm{g})$

Alkaloid Productivity $(\mathrm{mg} / \mathrm{L} /$ day $)=\{$ Alkaloid Production $(\mathrm{mg} / \mathrm{L}) /$ no. of days the product is harvested

Alkaloid Yield $(\% \mathrm{dwt})=\{$ Alkaloid Content $(\mathrm{mg} / \mathrm{g}) / 1000\} \times 100$

\subsection{Statistical Analysis}

The mean of three replicates of experiments, standard deviation, analysis of variance (ANOVA) of results were performed by using SPSS 15 package for Window [37] in the present study.

\section{RESULTS}

\subsection{Effect of Medium pH}

The $\mathrm{B} 5$ medium is devoid of $\mathrm{NH}_{4} \mathrm{NO}_{3}$ and contain only $\mathrm{KNO}_{3}$ as sources of nitrogen at a concentration lesser that present in MS medium. The results of the present study in B5 medium buffered at $\mathrm{pH} 4.51,5.82$ and 7.32 by addition of specific amount of molar solutions of (A) diammonium hydrogen phosphate $\left.\mathbf{( N H}_{4}\right)_{2} \mathbf{H P O}_{4}$ and (B) ammonium dihydrogen orthophosphate $\left(\mathrm{NH}_{4} \mathrm{H}_{2} \mathbf{P O}_{4}\right)$ for the enhanced supply of total nitrogen $\left(\mathrm{NH}_{4}{ }^{+}+\mathrm{NO}_{3}{ }^{-}\right)$and phosphate compared to MS medium on alkaloid production is presented in Table 1. 
Table 1. Effects of nitrogen and phosphate source (combination of diammonium hydrogen phosphate and ammonium dihydrogen orthophosphate) on modulation of medium $\mathrm{pH}$ for production of cellular biomass and yield of alkaloid in B5 suspension culture.

\begin{tabular}{|c|c|c|c|c|c|c|c|c|c|c|}
\hline \multirow[t]{2}{*}{$\begin{array}{l}\text { S1. } \\
\text { No. }\end{array}$} & $\begin{array}{l}\text { Volume } \\
\text { of } 1 \mathrm{M} \\
\text { (A) }\end{array}$ & $\begin{array}{c}\text { Volume of } \\
1 \mathrm{M}(\mathrm{B})\end{array}$ & $\begin{array}{c}\text { Total } \\
\text { nitrogen } \\
\text { conc. }\end{array}$ & \multirow[t]{2}{*}{$\mathrm{pH}$} & $\begin{array}{c}\text { Biomass Fresh } \\
\mathrm{wt}\end{array}$ & $\begin{array}{c}\text { Biomass Dry } \\
\text { wt }\end{array}$ & $\begin{array}{l}\text { Alkaloid } \\
\text { Content }\end{array}$ & $\begin{array}{c}\text { Alkaloid } \\
\text { Production }\end{array}$ & $\begin{array}{c}\text { Alkaloid } \\
\text { Productivity }\end{array}$ & Alkaloid Yield \\
\hline & (ml) & $(\mathrm{ml})$ & $(\mathrm{mg} / \mathrm{L})$ & & $\mathrm{g} / \mathrm{L}$ & $\mathrm{g} / \mathrm{L}$ & $\mathrm{mg} / \mathrm{g} \mathrm{dwt}$ & $\mathrm{mg} / 1$ & $\mathrm{mg} / \mathrm{L} / \mathrm{d}$ & $\% \mathrm{dwt}$ \\
\hline 1 & 0 & 0 & $\begin{array}{c}\text { MS Medium } \\
(2850)\end{array}$ & $5.80 \pm 0.2$ & $\begin{array}{r}16.806 \\
\pm 1.076\end{array}$ & $\begin{array}{c}1.668 \\
\pm 0.162\end{array}$ & $\begin{array}{r}5.575 \\
\pm 0.270\end{array}$ & $\begin{array}{r}9.276 \\
\pm 0.689\end{array}$ & $\begin{array}{r}0.662 \\
\pm 0.049\end{array}$ & $\begin{array}{c}0.558 \\
\pm 0.027\end{array}$ \\
\hline 2 & 10 & 90 & $\begin{array}{c}1167.33 \\
(3667.33)\end{array}$ & $4.51 \pm 0.2$ & $\begin{array}{l}12.541 \\
\pm 0.098\end{array}$ & $\begin{array}{r}1.463 \\
\pm 0.069\end{array}$ & $\begin{array}{r}4.717 \\
\pm 0.044\end{array}$ & $\begin{array}{r}6.900 \\
\pm 0.388\end{array}$ & $\begin{array}{r}0.493 \\
\pm 0.028\end{array}$ & $\begin{aligned} & 0.472 \\
\pm & 0.005\end{aligned}$ \\
\hline 3 & 35 & 65 & $\begin{array}{c}1210.10 \\
(3710.10)\end{array}$ & $5.82 \pm 0.2$ & $\begin{array}{r}19.166 \\
\pm 0.145\end{array}$ & $\begin{array}{r}2.096 \\
\pm 0.090\end{array}$ & $\begin{array}{r}5.844 \\
\pm 0.154\end{array}$ & $\begin{array}{r}12.239 \\
\pm 0.204\end{array}$ & $\begin{array}{c}0.874 \\
\pm 0.015\end{array}$ & $\begin{array}{r}0.584 \\
\pm 0.016\end{array}$ \\
\hline 4 & 60 & 40 & $\begin{array}{c}1252.48 \\
(3752.48)\end{array}$ & $7.32 \pm 0.2$ & $\begin{array}{l}11.407 \\
\pm 0.093\end{array}$ & $\begin{array}{r}1.317 \\
\pm 0.063\end{array}$ & $\begin{array}{r}4.483 \\
\pm 0.087\end{array}$ & $\begin{array}{r}5.905 \\
\pm 0.295\end{array}$ & $\begin{array}{r}0.422 \\
\pm 0.021\end{array}$ & $\begin{array}{r}0.448 \\
\pm 0.009\end{array}$ \\
\hline & $\mathrm{F}(3$ & ,11) & & & 79.140 & 23.115 & 36.757 & 90.961 & 91.490 & 36.838 \\
\hline & $\mathrm{P}<$ & 0.05 & & & 0.000 & 0.000 & 0.000 & 0.000 & 0.000 & 0.000 \\
\hline
\end{tabular}

The Gamborgh's (B5) suspension medium [34] was supplemented with 3\% sucrose (w/v) and modified with $0.50 \mathrm{mg} / \mathrm{L}$ of 2,4-D, $1.0 \mathrm{mg} / \mathrm{L}$ of Kinetin and 2.0 mg/L NAA. For increased $\mathrm{pH}$, total nitrogen and phosphorus, respective volume of $1 \mathrm{M}$ stock solution each of (A) diammonium hydrogen phosphate $\left(\mathrm{NH}_{4}\right)_{2} \mathrm{HPO}_{4}$ and $(\mathrm{B})$ ammonium dihydrogen orthophosphate $\left(\mathrm{NH}_{4} \mathrm{H}_{2} \mathrm{PO}_{4}\right)$ were mixed as shown in the table to get specific $\mathrm{pH}$ and the total amount of nitrogen and phosphorus in the medium. The suspension culture was established with 100-150 mg of callus (4-weeks) or by cell biomass (2- weeks) inoculated @ 20\% per culture vessel with $25 \mathrm{ml}$ medium. The growth of cell biomass in suspension culture was recorded after 2-week of subculture. 
The B5 medium maintained at lower $\mathrm{pH}(4.51 \pm 0.2)$ prevented the solidification of agar even at $2.5 \%$ concentration in the medium. While at higher $\mathrm{pH}(7.32 \pm 0.2)$ precipitation of nutrient salts was common both in agar and suspension conditions of B5 medium. This led to reduced biomass and alkaloid production at lower and higher $\mathrm{pH}$ even in the presence of elevated levels of nitrogen and phosphate even in the suspension medium. The B5 medium maintained at $\mathrm{pH}$ of $5.82 \pm 0.2$ by supplementing with elevated levels of nitrogen and phosphate was almost indispensable for enhanced production of biomass (fresh and dry weight) and alkaloids (content, production, productivity and the yield) compared to control cultures in MS suspension medium. All the observable parameters such as fresh and dry weight of biomass as well as content, production, productivity and the yield of alkaloid was significantly reduced at both higher or lower $\mathrm{pH}$ even though media contained elevated levels of both nitrogen and phosphorus. The possible reason for this reduction in response to the media $\mathrm{pH}$ had been reported in various studies discussed in the following section.

\subsection{Effect of Nitrogen and Phosphate}

The increased supply of nitrogen and phosphate source in B5 medium showed a significant effect on biomass (fresh and dry wt.) and alkaloid (content, production, productivity and yield) as compared to the MS medium (Table 1). Maximum biomass production (fresh wt., dry wt.) and yield of total alkaloid was obtained with elevated phosphate levels and total nitrogen concentration of $3710.10 \mathrm{mg} / \mathrm{L}$ compared to control MS medium with $2850 \mathrm{mg} / \mathrm{L}$ of total nitrogen (Table 1) both maintained at $5.8 \pm 0.2 \mathrm{pH}$. The B5 medium with $3667.33 \mathrm{mg} / \mathrm{L}$ of total nitrogen buffered at lower $\mathrm{pH}(4.51 \pm 0.2)$ or with $3752.48 \mathrm{mg} / \mathrm{L}$ of total nitrogen adjusted at higher $\mathrm{pH}(7.32 \pm 0.2)$ containing elevated levels of phosphate showed significant reduction in all the observable parameters compared to the control MS medium with normal levels of nitrogen and phosphate. These reductions might be attributed to the precipitation of nutrient salts as a function of medium $\mathrm{pH}$. Hence, the elevated levels of nitrogen and phosphate showed significant effects on all observable parameter as a function of $\mathrm{pH}$ of the medium.

\subsection{Effect of Nitrogen Phenylalanine and Tryptophan}

The effects of tryptophan or phenylalanine added in the medium as reduced sources of nitrogen showed significant $(\mathrm{P}<0.05)$ response on all the observable parameters (Table $2 \& 3$ ). Both the reduced sources of nitrogen followed similar response trend while tryptophan showed slightly better response compared to phenylalanine. There was continuous increase in all the observable parameters with the addition of either the tryptophan or phenylalanine. Hence, addition of $200 \mathrm{mg} / \mathrm{L}$ of either tryptophan or phenylalanine in the B5 medium was the threshold for maximum alkaloid yield as well as other parameters. 
Table 2. Effects of tryptophan and nitrogen source (combination of diammonium hydrogen phosphate and ammonium dihydrogen orthophosphate) on biomass production alkaloid yield.

\begin{tabular}{|c|c|c|c|c|c|c|c|}
\hline \multirow{2}{*}{$\begin{array}{l}\text { S1. } \\
\text { No. }\end{array}$} & $\begin{array}{l}\text { Tryptophan } \\
\text { Concentration }\end{array}$ & Biomass Fresh wt & Biomass Dry wt & Alkaloid Content & Alkaloid Production & Alkaloid Productivity & Alkaloid Yield \\
\hline & $\mathrm{mg} / \mathrm{L}$ & $\mathrm{g} / \mathrm{L}$ & $\mathrm{g} / \mathrm{L}$ & $\mathrm{mg} / \mathrm{g} \mathrm{dwt}$ & $\mathrm{mg} / \mathrm{L}$ & $\mathrm{mg} / \mathrm{L} / \mathrm{d}$ & $\% \mathrm{dwt}$ \\
\hline 1 & 0.0 & $17.987 \pm 0.122$ & $2.089 \pm 0.174$ & $5.972 \pm 0.160$ & $12.492 \pm 1.311$ & $0.892 \pm 0.093$ & $0.597 \pm 0.016$ \\
\hline 2 & 50 & $18.493 \pm 0.101$ & $2.293 \pm 0.080$ & $6.665 \pm 0.160$ & $15.287 \pm 0.895$ & $1.092 \pm 0.064$ & $0.666 \pm 0.016$ \\
\hline 3 & 100 & $18.947 \pm 0.122$ & $2.450 \pm 0.120$ & $7.306 \pm 0.203$ & $17.913 \pm 1.363$ & $1.279 \pm 0.097$ & $0.731 \pm 0.021$ \\
\hline 4 & 150 & $19.120 \pm 0.120$ & $2.672 \pm 0.083$ & $7.947 \pm 0.118$ & $21.240 \pm 0.847$ & $1.517 \pm 0.061$ & $0.794 \pm 0.012$ \\
\hline 5 & 200 & $19.387 \pm 0.061$ & $2.766 \pm 0.120$ & $8.844 \pm 0.231$ & $24.478 \pm 1.700$ & $1.748 \pm 0.121$ & $0.884 \pm 0.023$ \\
\hline \multicolumn{2}{|r|}{$\mathrm{F}(4,10)$} & 78.876 & 15.726 & 116.539 & 42.169 & 42.266 & 116.374 \\
\hline \multicolumn{2}{|r|}{$\mathrm{P}<0.05$} & 0.000 & 0.000 & 0.000 & 0.000 & 0.000 & 0.000 \\
\hline
\end{tabular}

The Gamborgh's (B5) suspension medium[34] was supplemented with 3\% sucrose (w/v) and modified with $0.50 \mathrm{mg} / \mathrm{L}$ of 2,4-D, $1.0 \mathrm{mg} / \mathrm{L}$ of Kinetin and 2.0 mg/L NAA. Additionally, the media was fortified with $35 \mathrm{ml}$ and $65 \mathrm{ml}$ of $1 \mathrm{M}$ stock solution each of (A) diammonium hydrogen phosphate $\left(\mathrm{NH}_{4}\right)_{2} \mathrm{HPO}_{4}$ and (B) ammonium dihydrogen orthophosphate $\left(\mathrm{NH}_{4} \mathrm{H}_{2} \mathrm{PO}_{4}\right)$ respectively to get enhanced amount of nitrogen, phosphorus and medium $\mathrm{pH}$ at 5.82 . This medium was further supplemented with $0-200$ mg/L tryptophan to study the combined effects of nitrogen source. The suspension culture was established with $100-150 \mathrm{mg}$ of callus (4-weeks) or by cell biomass (2- weeks) inoculated @ 20\% per culture vessel with $25 \mathrm{ml}$ medium. The growth of cell biomass in suspension culture was recorded after 2-week of subculture. 
Table 3. Effects of phenylalanine and nitrogen source (combination of diammonium hydrogen phosphate and ammonium dihydrogen orthophosphate) on biomass production alkaloid yield.

\begin{tabular}{|c|c|c|c|c|c|c|c|}
\hline \multirow{2}{*}{$\begin{array}{c}\text { Sl. } \\
\text { No. }\end{array}$} & $\begin{array}{c}\text { Phenylalanine } \\
\text { Concentration }\end{array}$ & Biomass Fresh wt & Biomass Dry wt & Alkaloid Content & Alkaloid Production & Alkaloid Productivity & Alkaloid Yield \\
\cline { 2 - 8 } & $\mathrm{mg} / \mathrm{L}$ & $\mathrm{g} / \mathrm{L}$ & $\mathrm{g} / \mathrm{L}$ & $\mathrm{mg} / \mathrm{g} \mathrm{dwt}$ & $\mathrm{mg} / \mathrm{L}$ & $\mathrm{mg} / \mathrm{L} / \mathrm{d}$ & $\% \mathrm{dwt}$ \\
\hline 1 & 0.0 & $17.600 \pm 0.080$ & $1.942 \pm 0.122$ & $5.742 \pm 0.247$ & $11.174 \pm 1.165$ & $0.798 \pm 0.083$ & $0.574 \pm 0.025$ \\
\hline 2 & 50 & $18.333 \pm 0.122$ & $2.106 \pm 0.101$ & $6.409 \pm 0.160$ & $13.502 \pm 0.891$ & $0.964 \pm 0.064$ & $0.641 \pm 0.016$ \\
\hline 3 & 100 & $18.800 \pm 0.120$ & $2.317 \pm 0.101$ & $7.049 \pm 0.248$ & $16.346 \pm 1.263$ & $1.167 \pm 0.090$ & $0.705 \pm 0.025$ \\
\hline 4 & 150 & $18.880 \pm 0.120$ & $2.499 \pm 0.080$ & $7.690 \pm 0.204$ & $19.229 \pm 1.104$ & $1.374 \pm 0.079$ & $0.769 \pm 0.020$ \\
\hline 5 & 200 & $19.280 \pm 0.160$ & $2.593 \pm 0.101$ & $8.664 \pm 0.248$ & $22.478 \pm 1.492$ & $1.606 \pm 0.107$ & $0.866 \pm 0.025$ \\
\hline & $\mathrm{F}(4,10)$ & 44.971 & 21.064 & 76.585 & 42.022 & 41.911 & 77.094 \\
\hline & $\mathrm{P}<0.05$ & 0.000 & 0.000 & 0.000 & 0.000 & 0.000 & 0.000 \\
\hline
\end{tabular}

The Gamborgh's (B5) suspension medium [34] was supplemented with 3\% sucrose (w/v) and modified with $0.50 \mathrm{mg} / \mathrm{L}$ of 2,4-D, 1.0 mg/L of Kinetin and 2.0 mg/L NAA. Additionally, the media was fortified with $35 \mathrm{ml}$ and $65 \mathrm{ml}$ of $1 \mathrm{M}$ stock solution each of (A) diammonium hydrogen phosphate $\left(\mathrm{NH}_{4}\right)_{2} \mathrm{HPO}_{4}$ and $(\mathrm{B})$ ammonium dihydrogen orthophosphate $\left(\mathrm{NH}_{4} \mathrm{H}_{2} \mathrm{PO}_{4}\right)$ respectively to get enhanced amount of nitrogen, phosphorurus and medium $\mathrm{pH}$ at 5.82 . This medium was further supplemented with $0-200$ $\mathrm{mg} / \mathrm{L}$ phenylalanine to study the combined effects of nitrogen source. The suspension culture was established with $100-150 \mathrm{mg}$ of callus (4-weeks) or by cell biomass (2weeks) inoculated @ 20\% per culture vessel with $25 \mathrm{ml}$ medium. The growth of cell biomass in suspension culture was recorded after 2-week of subculture. 


\section{DISCUSSION}

The growth of biomass and accumulation of products in cultured plant cells were dramatically altered by manipulating various media and environmental factors [38]. In the previous report enhanced production of biomass and alkaloid accumulation was optimized for the composition and strength of nutrient media, carbon source and plant growth regulators [3133]. The normal or single strength B5 medium supplanted with $3 \%$ sucrose (w/v) was found as the best choice for the optimal biomass accumulation and production of secondary metabolite in cell suspension culture of L. macranthoids [39] and C. roseus [31-33]. Li et al [39] observed similar trends in biomass and chlorogenic acid production using 6-BA $(2.0 \mathrm{mg} / \mathrm{L})$ and NAA $(0.5 \mathrm{mg} / \mathrm{L})$ in B5 suspension culture of Lonicera macranthoids. In the present study production of biomass (fresh wt. and dry wt.) and alkaloid (content, production, productivity and yield) was investigated in response to increased supply of nitrogen (inorganic and organic) and phosphorus in suspension culture using B5 medium buffered at varying $\mathrm{pH}$. The plant physiological process such as mineral nutrition, signaling, cell elongation, growth, development, environmental stress adaptation has been related to the $\mathrm{pH}$ of external media [40]. The $\mathrm{pH}$ of plant tissue culture media is mostly adjusted between 5 and 6 prior to the autoclaving which is dropped by 0.6 to 1.3 units after sterilization [41]. The cytosolic and vacuollar $\mathrm{pH}$ was increased by 3.0 and 1.3 units with a change in media $\mathrm{pH}$ from 4.5 to 6.3 in Chenopodium rubrum cell suspension culture [42] while the specific buffering potential was decreased continuously by $60 \%$ [40]. Production of biomass and withanolide A in Withania somnifera cell culture was not affected by media $\mathrm{pH}$ set at high or low. On the other hand Daucus carota cell culture excreted $90 \%$ of anthocyanin at 5.5 media $\mathrm{pH}$ than at 4.5 [43]. The release of secondary metabolites in to medium was due to cell membrane permeability associated with shift of media $\mathrm{pH}$ at low or high [44]. Reducing the media $\mathrm{pH}$ even for shorter time was found beneficial for up to 50\% release of betalains from Beta vulgaris transformed root culture system [45]. The flavonolignan content in Silybium marianum hairy root culture was maximum at 5.0 medium $\mathrm{pH}$ and decreased with the increase of $\mathrm{pH}$ to 5.7, 6, and 7 [46]. The growth and ginsenoside production in hairy root culture of ginseng was maximum when the initial $\mathrm{pH}$ of the medium adjusted between 6.0 to 6.5 prior to autoclaving and significantly reduced at initial $\mathrm{pH} 4.0$ or lower or above 7.0 [47]. Li et al [39] studied the effect of $\mathrm{pH}$ on the production biomass and chlorogenic acid in cell suspension cultures of Lonicera macranthoids. The highest biomass of $6.52 \mathrm{~g} / \mathrm{L}$ and $6.76 \mathrm{~g} / \mathrm{L}$ was achieved at 5.5 and 6.0 media $\mathrm{pH}$ respectively, showing maximum chlorogenic acid content. They found that production of biomass and secretion of chlorogenic acid was unaffected at higher or lower $\mathrm{pH}$ of the media, however, intracellular accumulation of acid was continued in medium at $\mathrm{pH}$ 7.0. Similar results were also observed in E. ulmoides cell suspension culture with maximum accumulation of chlorogenic acid at medium $\mathrm{pH}$ of 5.3 and continued production of chlorogenic acid up till the medium $\mathrm{pH}$ adjusted to 7.0 [48].

The inorganic and organic nutrients of culture media are easily manipulated for the enhanced and modified production of different chemical components of plant cells. In an earlier report Nowacki et al. [49] reported that the phosphate and nitrogen source provided by both ammonium di-hydrogen orthophosphate $\left(\mathrm{NH}_{4} \mathrm{H}_{2} \mathrm{PO}_{4}\right)$ and di-ammonium hydrogen phosphate $\left(\left(\mathrm{NH}_{4}\right)_{2} \mathrm{HPO}_{4}\right)$ helps in increasing the alkaloid production by converting the excess amino acids produced to secondary metabolites. When different levels of fructose, galactose, glucose and sucrose carbon source were compared, the medium containing 3\% sucrose showed maximum growth of cell biomass and the alkaloid yield [50]. In L. aestivum shoot culture, increased production of galanthamine was optimized applying different concentrations of sucrose, $\mathrm{NO}_{3}{ }^{-}$, $\mathrm{NH}_{4}{ }^{+}, \mathrm{PO}_{4}$ ions [51]. Culture medium supplied with enhanced nitrogen levels and the ratio of $\mathrm{NH}_{4}{ }^{+} / \mathrm{NO}_{3}{ }^{-}$(molar concentrations) showed to stimulate alkaloid synthesis. But the uptake of 
nitrate from medium and assimilation of ammonia by plant cell decreased the medium $\mathrm{pH}$ [52]. The uptake of nutrients and buffering components $\left(\mathrm{NH}_{4}{ }^{+}, \mathrm{NO}_{3}{ }^{-}, \mathrm{PO}_{4}{ }^{3+}\right)$ from the medium during initial growth phase or the acids (lactate, malate, succinate) secretion at the later stages in suspension culture caused change in hydrogen ion concentration affecting the secondary metabolite production [40;53]. An optimum of $90 \mathrm{mM}$ concentration of total nitrogen in 4:1 ratio of $\mathrm{NH}_{4}{ }^{+} / \mathrm{NO}_{3}{ }^{-}$in hairy roots culture of Anisodus acutangulus showed highest yield of tropane alkaloid from the maximum biomass produced [50]. The hairy roots induced from leaf explants culture of $A$. acutangulus was significantly affected by variations in media $\mathrm{pH}$. At $\mathrm{pH}$ 6.5 the hairy roots biomass increased two fold as compared to media with $\mathrm{pH} 4.5$. Whereas, at $\mathrm{pH} 4.5$ tropane alkaloid was produced with maximum yield [50]. Influence of external $\mathrm{pH}$ on alkaloid production and excretion by $C$. roseus resting cell suspensions reported [54]. In root cultures of Brugmansia candida production of scopolamine as well as hyoscyamine was increased at medium $\mathrm{pH} 5.5$ adjusted with acetic acid inducing the release of these alkaloids [55]. While these alkaloids were reduced significantly at $\mathrm{pH} 3.5$ and 4.5 , but a medium $\mathrm{pH}$ of 4.5 and above showed significant release of scopolamine and hyoscyamine. A change in cell membrane permeability stimulated by acetic or citric acid might be the cause for the release of these two alkaloids [55].

Both tryptophan and phenylalanine at all the levels in B5 medium showed highly significant increase in all the parameters in comparison to the standard control conditions. The highest growth was observed at $200 \mathrm{mg} / \mathrm{l}$ concentration of both the precursors across all parameters. A combination of the precursors along with the diammonium hydrogen phosphate and ammonium dihydrogen orthophosphate showed even higher response across all parameters. In conformity to the results of present study Whitmer et al. [56] reported that supplying tryptamine or tryptophan along with the iridoid precursors to transgenic cell lines $\mathrm{S} 1$ of $C$. roseus resulted in even further increase of alkaloid accumulation. Addition of a moderate concentration of reduced nitrogen source as L-glutamine followed by L-asparagine in medium also enhances the in vitro process of somatic embryo proliferation and maturation in C. roseus [57]. There was 2 fold increase in production of glucotropaeolin from Tropaeolum majus L. when phenylalanine and cystein fed as precursor amino acids in hairy root cultures [58]. Moreover, Cistanche deserticola cell culture fed with L- phenylalanine as precursor showed $75 \%$ higher phenylethanoid glycosides than the media without it [59]. On other hand, Namdeo et al. [60] reported that the key to successful protocol using precursor feeding to plant cell culture system lies in identification of cheapest by product of the other process which can be converted to desired secondary metabolites by selected plant cell line. Where as in $L$. macranthoids cell growth was inhibited by addition of phenylalanine at concentrations higher than $50 \mathrm{mg} / \mathrm{L}$ contrary to the content of chlorogenic acid which was gradually increased as compared to the control. The B5 medium added with $200 \mathrm{mg} / \mathrm{L}$ phenylalanine showed highest amount $(18.0 \mathrm{mg} / \mathrm{g} \mathrm{DW})$ of chlorogenic acid production [39]. The total alkaloid of the Fritillaria cirrhosa cultures was significantly improved by adding different concentration of phenylalanine [61]. Similarly, soybean cell suspension cultures showed increased content of daidzein when medium was supplemented with phenylalanine for $48 \mathrm{~h}$ [62].

Nutrients and environment conditions such as potassium nutrition [63], nitrogen nutrition [12], and salinity [15] showed enhanced accumulation of alkaloids in C. roseus. Plants exposed to excess UV-B radiation and other physical or chemical factors [64-66] produce serious oxidative stress response to tolerate them. Similarly, C. roseus cell suspension cultures supplied with adequate nitrogen source showed enhanced alkaloid production under UV-B treatment [67]. The yield and accumulation of UV absorbing compounds in liverwort was found changing dynamically in response to UV-B and photosynthetic radiations to revert the inhibition due to UV-B radiation [68]. Malik et al. [69] also showed that an optimum $\mathrm{pH}$ of 5.5-6.5 enhanced in vitro shikonins production from various species like Lithospermum, Arnebia, Alkanna, 
Anchusa, Echium and Onosma. Nitrogen is an important constituent of alkaloids and required for their synthesis while, phosphorus influence greatly the alkaloid synthesis in C. roseus L. [70]. Hassan et al. [71] showed enhanced alkaloid and other growth characteristics of C. roseus under the field application of nitrogen and potassium fertilizers. The highest yield of total alkaloid including the vincristine and vinblastine was obtained with maximum nitrogen but with lowest concentrations of potassium. Abdolzadeh et al. [72] found that feeding C. roseus plants with $11 \mathrm{mM}$ of total nitrogen (nitrate+ammonia) significantly enhanced the vincristine, vinblastine and the total alkalods production with increased cellular pool of nitrogen, amino acids and proteins. Nitrogen deficiency showed reduction in total chlorophyll content [73; 74]. While highest plant biomass in C. roseus was reported at $200 \mathrm{mg} \mathrm{N} \mathrm{dm}^{-3}$ in the substrate [70] and the highest yield of alkaloids was obtained at $300 \mathrm{mg} \mathrm{N} \mathrm{dm}^{-3}$ [75].

Further, An et al. [76] and Zhang et al. [77] have pointed out that nitrate reductasedependent nitric oxide signaling mediated the flavonoid accumulation in UV-B-induced plant leaves fed with nitrate. Adequate supply of nitrogen source showed significantly increased contents of $\mathrm{H}_{2} \mathrm{O}_{2}$ and MDA compared to control $C$. roseus plants indicating an enhanced tolerance to oxidative stress caused by UV-B radiation treatment [13]. The increased biosynthesis of different compounds with nitrogen, and alkaloids by extra nitrate supply might be involved in fighting the plants to various environmental and radiation stresses [13]. This hypothesis was further supported by the findings of unique catharanthine transporter as UV-Binduced signaling events under suspension cultures [67] and the involvement of ATP-binding cassette transporter with changing environmental conditions in C. roseus leaf surface cells [78].

Monnerat et al. [79] found that $C$. roseus plants supplied with nitrogen fertilizer in combinations with mycorrhizal fungi C. etunicatum, G. margarita and R. intraradices, showed increased production of ajmalicine. Hashemabadi et al. [80] reported enhanced level of leaf vindoline $(1.94 \mathrm{mg} / \mathrm{g} \mathrm{DW})$ and root alkaloid $(1.11 \mathrm{mg} / \mathrm{g} \mathrm{DW})$ and other plant characteristics by application of $40 \mathrm{mg} \mathrm{kg}^{-1}$ soil nitrogen fertilizer along with Azotobacter and fungal compost. A positively significant effect of plant growth promoting rhizobacteria (PGPR) on the alkaloid content of $C$. roseus was reported recently [81-84]. Similarly, application of PGPR on the induction of secondary metabolite synthesis, particularly of alkaloids had been presented earlier [85].

Hence, all these studies demonstrated that both biotic and abiotic stresses have either inductive, stimulatory or enhancing effects on the production of alkaloids and other secondary metabolites under the field conditions as well as in cell culture system of C. roseus and many other plants by enhanced organic or inorganic nitrogen and phosphorus supply in a $\mathrm{pH}$ dependent manner similar to our present study.

\section{CONCLUSION}

The callus and cell suspension culture technique has proven as a feasible alternative for enhancing the production of alkaloids and other secondary metabolite. Since, C. roseus are categorized as high nitrogen demanding plants which tolerate wide range of soil nutrients, salinity and $\mathrm{pH}$. Plants supplied with balanced level of essential nutrients have shown increased crop growth, biomass and yield of the various secondary metabolites. Applying similar strategies in cell suspension culture system would have positive effects on biomass and alkaloid accumulation. We found that B5 medium supplemented with enhanced levels of nitrogen and phosphorus as a combination of (A) diammonium hydrogen phosphate $\left.\mathbf{( N H}_{4}\right)_{2} \mathbf{H P O}_{4}$ and (B) ammonium dihydrogen orthophosphate $\left(\mathbf{N H}_{4} \mathbf{H}_{2} \mathbf{P O}_{4}\right)$ significantly affected all the observable parameters such as fresh and dry weight of cell biomass as well as alkaloid content, production, productivity and the yield in a $\mathrm{pH}$ dependent manner. The medium $\mathrm{pH}$ of 5.82 showed the maximum response of biomass and alkaloid yield while the lower and higher $\mathrm{pH}$ of the medium 
were slightly inhibitory compared to the control cultures established in MS medium. The enhanced alkaloid biosynthesis in response to increased total nitrogen $\left(\mathrm{NH}_{4}{ }^{+}+\mathrm{NO}_{3}{ }^{-}\right)$and phosphate at an adequate $\mathrm{pH}$ of test culture medium might caused by uptake and transport of these nutrients increasing the intracellular pool of nitrogen containing compounds and the intermediates of the pathway as supported by various published reports reffered in the present study. Addition of tryptophan or phenylalanine as reduced nitrogen source in B5 medium buffered at $5.82 \pm 0.2 \mathrm{pH}$ further enhanced the biomass and alkaloid production. There might be involvement of more complex interactions mechanisms of $\mathrm{pH}$, phosphate, organic and inorganic nitrogen as nutrient combined with other stresses to trigger the induction of alkaloid biosynthesis. There is need for further research to elucidate the mediation of molecular regulation and signaling mechanisms involved in the pathways leading to enhanced production of specific alkaloids.

\section{Acknowledgement}

The financial support provided by University Grant Commission, New Delhi for the major research project (F.: 42-207/2013 (SR) for the period 1.4.2013-31.3.2017) to the corresponding author is gratefully acknowledged.

\section{Contribution of authors}

All the experiments were executed and performed by Mr. Malay Ranjan Mishra. The second author Dr. Rajesh K. Srivastava constantly reviewed the experiments and results of various experiments. The experiment design and planning for execution of entire study was conducted by the corresponding author Dr. Nasim Akhtar to achieve the objective of the major research project sanctioned to him by the funding agency University Grant Commission, New Delhi (F.: 42-207/2013 (SR) for the period 1.4.2013-31.3.2017).

\section{Conflicts of Interest}

All the authors declared that there is no conflict of interest with regards to any part of the manuscript.

\section{ORCID}

Malay Ranjan Mishra (D) https://orcid.org/0000-0003-1714-0061

Rajesh Kumar Srivastava (iD https://orcid.org/0000-0001-5524-1045

Nasim Akhtar (iD) http://orcid.org/0000-0002-8867-985X

\section{REFERENCES}

[1]. Murashige, T., Skoog, F. (1962). A revised medium for rapid growth and bioassays with tobacco cultures. Physiol. Plant, 15, 473-497.

[2]. Kirkby, E.A. (1981). Plant growth in relation to nitrogen supply. Ecological Bulletins (Sweden), 33, 239-267.

[3]. Cramer, M.D., Lewis, O.A.M. (1993). The influence of $\mathrm{NO}^{3-}$ and $\mathrm{NH}^{4+}$ nutrition on the carbon and nitrogen partitioning characteristics of wheat (Triticum aestivum L.) and maize (Zea mays L.) plants. Plant and Soil, 154(2), 289-300.

[4]. Fabre, F., Planchon, C. (2000). Nitrogen nutrition, yield and protein content in soybean. Plant Science, 152(1), 51-58.

[5]. Ali, B., Hayat, S., Hayat, Q., Ahmad, A. (2010). Cobalt stress affects nitrogen metabolism, photosynthesis and antioxidant system in chickpea (Cicer arietinum L.). Journal of Plant Interaction, 5, 223-231.

[6]. Guo, X.R., Zu, Y.G., Tang, Z.H. (2012). Physiological responses of Catharanthus roseus to different nitrogen forms. Acta Physiologiae Plantarum, 34, 589-598. 
[7]. Bhadra, R., Shanks, J.V. (1997). Transient studies of nutrient uptake, growth, and indole alkaloid accumulation in heterotrophic cultures of hairy roots of Catharanthus roseus. Biotechnology and bioengineering, 55(3), 527-534.

[8]. Garnier, F., Carpin, S., Label, P., Crèche, J., Rideau, M., Hamdi, S. (1996). Effect of cytokinin on alkaloid accumulation in periwinkle callus cultures transformed with a lightinducible ipt gene. Plant Science, 120(1), 47-55.

[9]. Morgan, J.A., Barney, C.S., Penn, A.H., Shanks, J.V. (2000). Effects of buffered media upon growth and alkaloid production of Catharanthus roseus hairy roots. Applied microbiology and biotechnology, 53(3), 262-265.

[10]. Morrison K.M., Simmons, S.J., Stapleton, A.E. (2010). Loci controlling nitrate reductase activity in maize: ultraviolet $\mathrm{B}$ signaling in aerial tissues increases nitrate reductase activity in leaf and root when responsive alleles are present. Physiologia Plantarum, 140, 334-341.

[11]. Marschner, M. (1995). Mineral Nutrition of Higher Plants. 2nd Edn., Academic Press, London, New York, pp. 200-255; ISBN-10: 0124735436.

[12]. Kaul, K., Hoffman, S.A. (1993). Ammonium ion inhibition of Pinus strobus L. callus growth. Plant Science, 88(2), 169-173.

[13]. Guo, X.R, Chang, B.W, Zu, Y.G., Tang, Z.H. (2014). The impacts of increased nitrate supply on Catharanthus roseus growth and alkaloid accumulations under ultraviolet-B stress. Journal of Plant Interactions, 9(1), 640 - 646. DOI: 10.1080/17429145.2014.886 728

[14]. Lau, T.S.L., Eno, E., Goldstein, G., Smith, C., Christopher, D.A. (2006). Ambient levels of UV-B in Hawaii combined with nutrient deficiency decrease photosynthesis in nearisogenic maize lines varying in leaf flavonoids: flavonoids decrease photoinhibition in plants exposed to UV-B. Photosynthetica, 44, 394-403.

[15]. Tang, Z.H, Liu, Y.J., Guo, X.R., Zu, Y.G. (2011). The combined effects of salinity and nitrogen forms on Catharanthus roseus: the role of internal ammonium and free amino acids during salt stress. Journal of Plant Nutrition Soil Science, 174, 135-144.

[16]. Smith, A.M., Stitt, M. (2007). Coordination of carbon supply and plant growth. Plant Cell \& Environment, 30, 1126-1149.

[17]. Zhong, J.J., Wang, S.J. (1998). Effects of nitrogen source on the production of ginseng saponin and polysaccharide by cell cultures of Panax quinquefolium. Process biochemistry, 33(6), 671-675.

[18]. Hahn, E.J., Kim, Y.S., Yu, K.W., Jeong, C.S., Paek, K.Y. (2003). Adventitious root cultures of Panax ginseng CV Meyer and ginsenoside production through large-scale bioreactor system. Journal of plant biotechnology, 5(1), 1-6.

[19]. Uozumi, N., Makino, S., Kobayashi, T. (1995). 20-Hydroxyecdysone production in Ajuga hairy root controlling intracellular phosphate content based on kinetic model. Journal of fermentation and bioengineering, 80(4), 362-368.

[20]. Van Gulik, W.M., Ten Hoopen, H.J.G., Heijnen, J.J. (1993). A structured model describing carbon and phosphate limited growth of Catharanthus roseus plant cell suspensions in batch and chemostat culture. Biotechnology and Bioengineering, 41(8), 771-780.

[21]. Correia, J.J., Lobert, S. (2001). Physiochemical aspects of tubulin-interacting antimitotic drugs. Current pharmaceutical design, 7(13), 1213-1228.

[22]. Isah, T., Umar, S., Mujib, A., Sharma, M.P., Rajasekharan, P.E., Zafar, N.,' Frukh, A. (2018). Secondary metabolism of pharmaceuticals in the plant in vitro cultures: strategies, approaches, and limitations to achieving higher yield. Plant Cell, Tissue \& Organ Culture (PCTOC), 132, 239-265. 
[23]. El-Sayed M, Verpoorte R. (2007). Catharanthus terpenoid indole alkaloids: biosynthesis and regulation. Phytochemistry Reviews, 62, 277-305. DOI:10.1007/s11101-0069047-8

[24]. Buchanan, B.B., Gruissem, W., Jones, R.L. (2000). Biochemistry \& molecular biology of plants (Vol. 40). Rockville, MD: American Society of Plant Physiologists.

[25]. Van Der Heijden, R., Jacobs, D.I., Snoeijer, W., Hallared, D., Verpoorte, R. (2004). The Catharanthus alkaloids: Pharmacognosy and Biotechnology. Current Medicinal Chemistry, 11, 607-628.

[26]. Moreno, P.R., van der Heijden, R., Verpoorte, R. (1994). Elicitor-mediated induction of isochorismate synthase and accumulation of 2, 3-dihydroxy benzoic acid in Catharanthus roseus cell suspension and shoot cultures. Plant cell reports, 14(2-3), 188-191.

[27]. Shanks, J.V., Rijhwani, S.K., Morgan, J., Vani, S., Bhadra, R., Ho, C.H. (1999). Quantification of metabolic fluxes for metabolic engineering of plant products. In Plant cell and tissue culture for the production of food Ingredients Springer, Boston, MA. 1999; pp. 45-60.

[28]. Baldi, A., Dixit, V.K. (2008). Yield enhancement strategies for artemisinin production by suspension cultures of Artemisia annua. Bioresource technology, 99(11), 4609-4614.

[29]. Zeng, Y., Yan, F., Tang, L., Chen, F. (2003). Increased crocin production and induction frequency of stigma-like-structure from floral organs of Crocus sativus L. by precursor feeding. Plant Cell, Tissue and Organ Culture, 72(2), 185-191.

[30]. Seitz, H.U., Eilert, U., De Luca, V., Kurz, W.G.W. (1989). Elicitor-mediated induction of phenylalanine ammonia lyase and tryptophan decarboxylase: accumulation of phenols and indole alkaloids in cell suspension cultures of Catharanthus roseus. Plant cell, tissue and organ culture, 18(1), 71-78.

[31]. Mishra, M.R., Srivastava, R.K., Akhtar, N. (2018a). Enhancing alkaloid production from cell culture system of Catharanthus roseus with different carbon sources. European Journal of Biotechnology and Bioscience, 6(5), 12-20.

[32]. Mishra, M.R., Srivastava, R.K., Akhtar, N. (2018b). Enhanced Alkaloid Production from Cell Culture System of Catharanthus roseus in Combined Effect of Nutrient Salts, Sucrose and Plant Growth Regulators. Journal of Biotechnology and Biomedical Science 1(4). 14-34. DOI: 10.14302/issn.2576-6694.jbbs-18-247픈

[33]. Mishra, M.R., Srivastava, R.K., Akhtar, N. (2019). Abiotic stresses of salinity and water to enhance alkaloids production in cell suspension culture of Catharanthus roseus. Global Journal of Bio-Science and Biotechnology, 9(1), 7-14.

[34]. Gamborg, O.L., Miller, R., Ojima, K. (1968). Nutrient requirements of suspension cultures of soybean root cells. Experimental Cell Research, 50(1), 151-158.

[35]. Kalidass, C., Ramasamy, M.V., Daniel, A. (2010). Effect of auxin and cytokinin on vincristine production by callus cultures of Catharanthus roseus L.(apocynaceae). Tropical and Subtropical Agroecosystems, 12, 283-288.

[36]. Sreevidya, N., Mehrotra, S. (2003). Spectrophotometric method for estimation of alkaloids precipitable with Dragendorff's reagent in plant materials. Journal of $A O A C$ International, 86(6), 1124-1127.

[37]. SPSS Inc. Released (2006). SPSS for Windows, Version 15.0. Chicago, SPSS Inc.

[38]. Naeem, M., Aftab, T., Khan, M.M.A. (eds) (2017). Catharanthus roseus: Current Research and Future Prospects. Springer International Publishing AG, Cham, 412pp. https://doi.org/10.1007/978-3-319-51620-2

[39]. Li, Q., Tang, M., Tan, Y., Ma, D., Wang. Y., Zhang, H. (2016). Improved production of chlorogenic acid from cell suspension cultures of Lonicera macranthoids. Tropical Journal of Pharmaceutical Research, 15(5), 919-927. http://dx.doi.org/10.4314/tjpr. $\underline{\mathrm{v} 15 \mathrm{i} 5.4}$ 
[40]. Wongchai, C., Chaidee, A., Pfeiffer, W. (2012). Multivariate analyses of salt stress and metabolite sensing in auto- and heterotroph Chenopodium cell suspensions. Plant Biology, 14, 129-141.

[41]. Nagella, P., Murthy H. N. (2010). Establishment of cell suspension cultures of Withania somnifera for the production of withanolide A. Bioresource Technology, 101(17), 67356739.

[42]. Herzbeck, H., Husemann, W. (1985). Photosynthetic carbon metabolism in photosynthetic cell suspension culture of Chenopodium rubrum L. In: Karl-Hermann Neumann, Wolfgang Barz, Ernst Reinhard (eds). Primary and secondary metabolism of plant cell culture: Part 1, Springer-Verlag Berlin Heidelberg. 15-23. 10.1007/978-3-642-7071792.

[43]. Ramawat, K. G. (1999). Production in Culture: Optimization In: Ramawat K.G. Merillon, J.M. (Eds). Biotechnology Secondary Metabolites, Science Publisher, USA, pp 123-143.

[44]. Asada, M., Shuler, M. L. (1989). Stimulation of ajmalicine production and excretion from Catharanthus roseus: effects of adsorption in situ, elicitors and alginate immobilization. Applied microbiology and biotechnology, 30(5), 475-481.

[45]. Mukundan, U., Bhide, V., Singh, G., Curtis, W.R. (1998). pH-mediated release of betalains from ransformed root cultures of Beta vulgaris L. Applied Microbiology and Biotechnology, 50(4), 241-245.

[46]. Rahimi, Sh., Hasanloo, T. (2016). The effect of temperature and $\mathrm{pH}$ on biomass and bioactive compounds production in Silybum marianum hairy root cultures. Research Journal of Pharmacognosy, 3(2), 53-59.

[47]. Sivakumar, G., Yu, K.W., Hahn, E.J., Paek, K.Y. (2005). Optimization of organic nutrients for ginseng hairy roots production in large-scale bioreactors. Current Science, 89(4), 641-649.

[48] Wang Y, Ye Q, Zhu Y. (2008). Preliminary study on the cell suspension culture of Eucommia ulmoides and secondary metabolite-chlorogenic acid. Guihaia, 5, 024.

[49]. Nowacki, E., Jurzysta, M., Gorski,. P., Nowacka, D., Waller, G.R. (1976). Effect of Nitrogen Nutrition on Alkaloid Metabolism in Plants. Biochemie und Physiologie der Pflanzen, 169, 231-240.

[50]. Liu, Q., Cui, L., Guo, Y., Ni, X., Zhang, Y., Kai, G. (2013). Optimization of nutritive factors in culture media for growth and tropane alkaloid production from Anisodus acutangulus hairy roots. Journal of Applied Pharmaceutical Science, 301, 001-004. DOI: 10.7324/ JAPS.2013.30101

[51]. Georgiev, V., Berkov, S., Georgiev, M., Burrus, M., Codina, C., Bastida, J., Ilieva, M., Pavlov, A. (2009). Optimized nutrient medium for galanthamine production in Leucojum aestivum L. in vitro shoot system. Zeitschrift für Naturforschung C, 64(3-4), 219-224.

[52]. McDonald, K. A., Jackman, A. P. (1989). Bioreactor studies of growth and nutrient utilization in alfalfa suspension cultures. Plant cell reports, 8(8), 455-458.

[53]. Endress, R. (Eds) (1994). Plant Cell as producers of Secondary compounds. In: Plant cell biotechnology Berlin: Springer-Verlag. Pp. 121-251.

[54]. Nef, C., Ambid, C., Fallot, J. (1987). Influence of External pH on Alkaloid Production and Excretion by Catharanthus Roseus Resting Cell Suspensions. In: Marin B. (eds) Plant Vacuoles. NATO ASI Series (Series A: Life Sciences), Springer, Boston, MA, vol 134.

[55]. Pitta-Alvarez, S.I., Giulietti, A.M. (1999). Influence of chitosan, acetic acid and citric acid on growth and tropane alkaloid production in transformed roots of Brugmansia candida Effect of medium $\mathrm{pH}$ and growth phase. Plant cell, tissue and organ culture, 59(1), 3138. 
[56]. Whitmer, S., van der Heijden, R., Verpoorte, R. (2002). Effect of precursor feeding on alkaloid accumulation by a strictosidine synthase over-expressing transgenic cell line S1 of Catharanthus roseus. Plant cell, tissue and organ culture, 69(1), 85-93.

[57]. Aslam, J., Mujib, A., Fatima, S., Sharma, M.P. (2008). Cultural conditions affect somatic embryogenesis in Catharanthus roseus L.(G.) Don. Plant Biotechnology Reports, 2(3), 179.

[58]. Wielanek, M., Urbanek, H. (2006). Enhanced glucotropaeolin production in hairy root cultures of Tropaeolum majus L. by combining elicitation and precursor feeding. Plant cell, tissue and organ culture, 86(2), 177-186.

[59]. Ouyang, J., Wang, X.D., Zhao, B., Wang, Y.C. (2005). Enhanced production of phenylethanoid glycosides by precursor feeding to cell culture of Cistanche deserticola. Process Biochemistry, 40(11), 3480-3484.

[60]. Namdeo, A.G., Jadhav, T.S., Rai, P.K., Gavali, S., Mahadik, K.R. (2007). Precursor feeding for enhanced production of secondary metabolites: a review. Pharmacognosy Reviews, 1(2), 227.

[61]. Yuehua, W. (2011). Effect of different amino acid precursorfeeding on the active ingredient of Fritillaria cirrhosa D. Don culture. Journal of Anhui Agricultural Science, 24, 026.

[62]. Liang, X., Zhu, X., Li, H. (2009). Effects of precursor and elicitor on isoflavone accumulation in cell-suspension cultures of soybean. J Xiamen Univ (Natural Science), 1,028 .

[63]. Chang, B.W., Cong, W.W., Chen, Q., Zu, Y.G., Tang, Z.H. (2014). The influence of different forms and concentrations of potassium nutrition on growth and alkaloid metabolism in Catharanthus roseus seedlings. Journal of plant interactions, 9(1), 370377.

[64]. Lidon, F.C., Ramalho, J.C. (2011). Impact of UV-B irradiation on photosynthetic performance and chloroplast membrane components in Oryza sativa L. Journal of Photochemistry and Photobiology B: Biology, 104, 457-466.

[65]. Singh, V.P., Srivastava, P.K., Prasad, S.M. (2012). Differential effect of UV-B radiation on growth, oxidative stress and ascorbate-glutathione cycle in two cyanobacteria under copper toxicity. Plant Physiology and biochemistry, 61, 61-70.

[66]. Singh, S., Agrawal, M., Agrawal, S.B. (2013). Differential sensitivity of spinach and Amaranthus to enhanced UV-B at varying soil nutrient levels: association with gas exchange, UV-B-absorbing compounds and membrane damage. Photosynthesis Research, 115, 123-138.

[67]. Ramani. S., Chelliah, J. (2007). UV-B-induced signaling events leading to enhancedproduction of Catharanthine in Catharanthus roseus cell suspension cultures. BMC Plant Biology, 7, 61.

[68]. Fabon, G., Monforte, L., Tomas-Las-Heras, R., Nunez-Olivera, E., Martinez-Abaigar, J. (2012). Dynamic response of UV absorbing compounds, quantum yield and the xanthophylls cycle to diel changes in UV-B and photosynthetic radiations in an aquatic liverwort. Journal of Plant Physiology, 169(1), 20-26.

[69]. Malik, S., Bhushan, S., Sharma, M., Ahuja, P.S. (2016). Biotechnological approaches to the production of shikonins: a critical review with recent updates. Critical reviews in biotechnology, 36(2), 327-340.

[70]. Lata, B. (2007). Cultivation, mineral nutrition and seed production of Catharanthus roseus (L.) G. Don in the temperate climate zone. Phytochemistry Review, 6, 403-411.

[71]. Hassan, R.A., Habib, A.A., El-Din, A.A.E. (2009). Effect of nitrogen and potassium fertilization on growth, yield and alkaloidal content of periwinkle (Catharanthus roseus 
G. Don). Medicinal and Aromatic Plant Science and Biotechnology, 3(special issue), 2426.

[72]. Abdolzadeh, A., Hosseinian, F., Aghdasi, M., Sadgipoor, H. (2006). Effects of nitrogen sources and levels on growth and alkaloid content of periwinkle. Asian Journal of Plant Sciences, 5(2), 271-276.

[73]. Shangguan, Z.P., Shao, M.A., Dyckmans, J. (2000). Nitrogen nutrition and water stress effects on leaf photosynthetic gas exchange and water use efficiency in winter wheat. Environmental and Experimental Botany, 44(2), 141-149.

[74]. Singh, A., Agrawal, M. (2015). Effects of ambient and elevated $\mathrm{CO}_{2}$ on growth, chlorophyll fluorescence, photosynthetic pigments, antioxidants, and secondary metabolites of Catharanthus roseus (L.) G. Don. grown under three different soil N levels. Environmental Science and Pollution Research, 22, 3936-3946.

[75]. Łata, B., Sadowska, A. (1996). Effect of nitrogen level in the substrate on yield and alkaloid content in Catharanthus roseus L. (G) Don. Folia Horticulturae, 8(2), 59-69.

[76]. An, L., Liu, Y., Zhang, M., Chen, T., Wang, X. (2005). Effects of nitric oxide on growth of maize seedling leaves in the presence or absence of ultraviolet-B radiation. Journal of Plant Physiology, 162, 317-326.

[77]. Zhang, M., Dong, J.F., Jin, H.H., Sun, L.N., Xu, M.J. (2011). Ultraviolet- B-induced flavonoid accumulation in Betula pendula leaves is dependent upon nitrate reductasemediated nitric oxide signaling. Tree Physiology, 31(8), 798-807.

[78]. Yu, F., De Luca, V. (2013). ATP-binding cassette transporter controls leaf surface secretion of anticancer drug components in Catharanthus roseus. Proceedings of the National Academy of Science USA, 110(39), 15830-15835.

[79]. Monnerat, C.S., Freitas, M.S. ., Vieira, I.J.C., Martins, M.A., Carvalho, A.J.C., de Santos, P.C dos, Lima, T.C. (2018). Ajmalicine bioproduction in Catharanthus roseus (L) G. Don inoculated with arbuscular mycorrhiza and fertilized with nitrogen. Revista Brasileira de Ciência do Solo., 42, e0170057

[80]. Hashemabadi, D., Sabzevari, F., Kaviani, B., Ansari, M.H. (2018). Organic N-fertilizer, rhizobacterial inoculation and fungal compost improve nutrient uptake, plant growth and the levels of vindoline, ajmalicine, vinblastine, catharanthine and total alkaloids in Catharanthus roseus L. Folia Horticulturae, 30(2), 21-31. DOI: 10.2478/fhort-20180018.

[81]. Karthikeyan, B., Abdul Jaleel, C., Azooz, M.M. (2009). Individual and combined effects of Azospirillum brasilense and Psudomonas fluorescens on biomass yield and ajmalicine production in Catharanthus roseus. Academic Journal of Plant Sciences, 2(2), 69-73.

[82]. Karthikeyan, B.N., Joe, M.M., Abdul Jaleel, C., Deiveekasundaram, M. (2010). Effect of root inoculation with plant growth promoting rhizobacteria (PGPR) on plant growth, alkaloid content and nutrient control of Catharanthus roseus (L.) G. Don. Natura Croatica, 19(1), 205-212.

[83]. Attia, F.A., Saad, O.A.O. (2001). Bio-fertilizers as partial alternative of chemical fertilizer for Catharanthus roseus G. Don. J. Agric. Sci., Mansoura Univ., 26(11), 7193-7208.

[84]. Jaleel, C.A., Manivavannan, P., Sankar, B., Kishorekumar, A., Gopi, R., Somasundaram, R., Panneerselvam, R. (2007). Psudomonas fluorescens enhances biomass yield and ajmalicine production in Catharanthus roseus under water deficit stress. Colloids and Surfaces B: Biointerfaces, 60(1), 7-11.

[85]. Khalid, A., Arshad, M., Zahir, Z.A. (2004). Screening plant growth-promoting rhizobacteria for improving growth and yield of wheat. Journal of Applied Microbiology, 96(3), 473-480. 